\title{
DRIVERS OF CHINA'S FOREIGN DIRECT INVESTMENT INTO AFRICA
}

\section{Jorge Braga de Macedo, Luís Brites Pereira and José Mário Lopes*}

March 30, 2009

\begin{abstract}
We assess the determinants of Chinese direct investment in Africa compared with those of global FDI. We find that economic size and macroeconomic stability are positively correlated with Chinese and global FDI in Africa. Institutional variables, such as accountability and rule of law, are not significant in either case and the same can be said about FDI-aid complementarities. The presence of oil is a determinant of Chinese FDI but not of global FDI into Africa. Conversely, the openness of the economy is a determinant for global FDI but not of Chinese FDI, which appears to favour closed economies possibly due to industrial organizational concerns. While these differences accord with intuition, we find no evidence for the claim that Chinese FDI in Africa is related to non-economic governance in a specific way that differs from global practice. More refined governance indicators should be used to verify whether Chinese and global FDI into Africa remain indistinguishable on this score: we plan to do this in future research.
\end{abstract}

JEL Classification:

Keywords: Foreign Direct Investment, China-Africa economic relations,

\section{Contacts:}

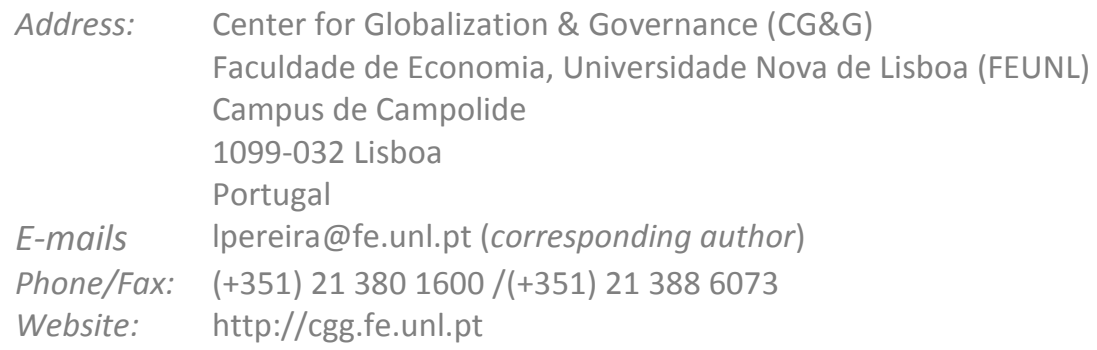

\footnotetext{
* An earlier version of this paper was discussed at an ancillary meeting of the 2008 Annual Bank Conference on Development Economics (ABCDE), organised by the Centre for Chinese Studies, University of Stellenbosch on June 12, 2008 in Cape Town, South Africa. The comments received are gratefully acknowledged and the usual disclaimer applies.
} 


\section{DRIVERS OF CHINA'S FOREIGN DIRECT INVESTMENT INTO AFRICA}

\section{INTRODUCTION}

Investing in China's booming economy has been a salient world feature since the mid 1980s. The main reason for the attraction of Foreign Direct Investment (FDI) lies with China's pursuit of market-orientated reforms, coupled with a large internal market and low production costs. The fact that China itself began to invest heavily abroad, using the proceeds from its growing trade surplus, from the early 1990s onwards is less recognized. Nevertheless, the recent surge in Chinese investment, especially in Africa, has drawn considerable attention from policy-makers and academics, who seek to understand whether it is being driven by a possible "China-Africa factor".

[Figures 1 to 4 here]

The recent trends in inward and outward African and Chinese FDI are depicted in Figures 1 to 4 . Not unexpectedly, they reveal that inward FDI is still far greater than outward FDI in both cases. It is striking, however, that the 2006 stock of Chinese outward FDI (in millions of US\$) was 13 times greater when compared to its 1991 level. Moreover, China's outward flows also increased dramatically, especially from the mid 1990s onwards

[Figures 5 to 7 here]

As for the geographical dispersion of China's outward FDI, Figures 5 and 6 show that Latin America and Asia account for the lion's share of both stocks and flows. At first sight, this observation may suggest that Africa does not feature prominently in China's international investment strategy. However, if we exclude these two regions, we observe that, in relative terms, Chinese outward FDI is increasingly targeting Africa and less so North America and Oceania. Africa clearly matters for China, as demonstrated by the recent investments in Sudanese infrastructure (Figure 7). 
Indeed, Wang (2007) ${ }^{1}$ reports that China has either become a major market, donor, financier, investor or a combination of these roles for many African countries. In general, it is fair to say, that China's current engagement in Africa is primarily trade and investment rather than aid-related and that the private sector's role in it is increasingly more pronounced. As for Chinese investment in Africa, the big surge occurred in 2003 following the implementation of China's strategic "going out" policy. As a result, outflows to Africa increased from under 100 million US\$ to more than 500 million US\$ during the period 2003 to 2006 .

In this paper, we use aggregate data on the drivers of China's FDI into Africa and compare them to those of global FDI into Africa to better understand China's engagement with the continent. Specifically, we consider the role of macroeconomic stability, degree of openness, oil as well as that of the rule of law and accountability. The inclusion of the two latter variables is motivated by many observers' contention that China disregards these important institutions when pursing its investment strategy. Indeed, China explicitly acknowledges that it is not its business to interfere in domestic concerns. As early as 1964, the Chinese premier Zhou Enlai defined the "Eight Principles for China's Aid to Foreign Countries". One of these, $\boldsymbol{T}_{\boldsymbol{T}}$ states that "in providing aid to other countries, the Chinese Government strictly respects the sovereignty of the recipient countries". As such, we want to know whether there is empirical evidence for this contention.

Our paper is structured as follows. In section 2 , we briefly describe the determinants for FDI based on different categorizations found in the literature. Section 3 discusses our estimation results while section 4 concludes.

\section{DRIVERS OF FOREIGN DIRECT INVESTMENT}

Modern FDI theory follows Stephen Hymer² (1934-1974)'s seminal doctoral thesis at MIT, written in 1960 and published in 1976. He claimed that the main determinants of FDI are industrial organization, rather portfolio investment concerns. Rather than explaining these capital flows via interest rate differentials, Hymer emphasized market imperfections instead. He considered control and market share to be the principal forces driving force of 
FDI, through which firms find it optimal to keep control of production. This control allows them either to suppress competition, or to appropriate rents derived from advantages like skilled labour, cheap raw materials, access to capital markets or technology. He subsequently complemented this perspective by describing the reasons behind vertical integration (to overcome negotiation problems due to market imperfections such as bilateral oligopoly, to diversify the enterprise's assets, and to allow information to circulate better within the corporation) and horizontal integration (to avoid the risk of a licensee using the information to compete against the multinational enterprise, and because greater profits simply result in easier collusion). Later related work, undertaken by Williamson $(1975)^{3}$, also put forward transaction costs as being another driving force behind FDI.

Following Hymer's contribution, Dunning $(1993)^{4}$ identifies four determinants of FDI based on three possible types of competitive advantages, which are also discussed in Zhou and Lall (2005). ${ }^{5}$ With respect to the competitive advantages, one may broadly speak of: ownership-specific advantages (related to capital, either human or physical, technology, management, etc.); location-specific advantages (arising from economic, social or political advantages of investing in a specific location); and, internalisation advantages (related to the nature of investment, e.g. whether it is better to merge or to install productive capacity single-handedly).

These, in turn, lead to four motives for investing abroad: market-seeking, (foreign investors are attracted by the size of the domestic market and/or its investment climate); resource-seeking (a country's natural resources attract multinational corporations (MNCs), who also may seek out labour-abundant countries with good production facilities and infrastructure); asset-seeking (MNCs seek to establish strong asset positions in order to fulfil their long run commercial and other goals; and, lastly, efficiency-seeking (MNCs seek to achieve economies of scale through their expansion abroad).

More recent literature has put forward new categorisations that complement and extend previous ones. For instance, Asiedu (2002) ${ }^{6}$ and Asiedu and Lien (2004) ${ }^{7}$ focus on natural resources, openness, political risk and infrastructure. Broadman (2007), meanwhile, defines three groups of factors that affect trade and foreign direct investment between Africa and Asia: these are "at-the-border" policies (such as tariffs, quotas and trade or investment agreements); "behind-the-border" conditions (such as market structures, the 
quality of institutions, infrastructure and macroeconomic environment) and "between-theborder" conditions (which relates to logistical simplification, information and/or ethnic networks that help disseminate the perception of opportunities abroad).

In the Chinese case, the emergence of large state-owned companies endowed with considerable reserves has allowed for significant investment in Asia, Latin America and Africa. One of the reasons frequently cited regarding China's interest in Africa is its desire to ensure a reliable supply of much-needed commodities, such as crude oil amongst others. This corresponds to an essentially resource-seeking motive. Indeed, Broadman (2007) ${ }^{8}$ finds, using UNCTAD data, that crude oil accounts for over 60 percent of African exports to China. Other items are found to have a much smaller weight in export make-up, e.g. the diamonds that China imports, almost exclusively from South Africa, accounts for around three percent only.

In the next section, we seek to understand what drive's China's FDI in Africa. In doing so, we focus on "behind-the-border" conditions in accordance with the typologies presented in Asiedu (2002) and Broadman (2007). Note that, by design, our study does not address the so-called "Africa factor" that is referred to by Asiedu (2002). Under this viewpoint, good institutions, more flexible markets and a better prepared working force alone do not explain FDI flows into the African continent, and so geography is also considered to be an important FDI determinant.

\section{ESTIMATION RESULTS}

The data have been collected from various sources. Data on Chinese FDI into Africa comes from the MOFCOM $(2006)^{9}$ report while the World Development Indicators CD-ROM provides data on inflation, degree of openness, GDP, population, and global FDI and aid into each African country. The data on Africa's export structure and China's import structure comes from Broadman (2007). We use Brautigam (2008) ${ }^{10}$ to obtain data on the loan agreements between China and African countries while data on governance were drawn from Kaufmann et al. (2006) $)^{11}$ and the Heritage Foundation. Our sample is a panel data covering all African countries for the period 2003-2006. As such, it has a stronger crosssection dimension than a time-series one and all corresponding asymptotic theory applies. 
We recognise that the models used previously to study the driver's of FDI vary considerably depending on the exact research question being addressed, as well as on data availability which is know to be a serious issue for many African countries. Moreover, the accuracy of Chinese data has also been disputed (see Wang, 2007). With these caveats in mind, we estimate the following model:

$\log F D I_{i, t}=c+\alpha_{1} \log G D P_{i, t}+\alpha_{2} \log$ Surface $_{i}+\alpha_{3} \log$ Pop $_{i, t}+\alpha_{4}$ Openness $_{i, t}+\alpha_{5}$ Inflation $_{i, t}+$ $+\alpha_{6}$ Oil $_{i, t}+\alpha_{7}$ Institutions $_{i, t}+\alpha_{8}$ Aid $_{i, t}+\varepsilon_{i, t}$

where $\log F D I$ and $\log G D P$ respectively represent the logarithms of real Foreign Direct Investment and Gross Domestic Product; logPop is the logarithm of population; logSurf is the logarithm of surface area; Openness is the degree of openness (measured by the volume of trade divided by GDP); Oil is a dummy variable reflecting the fact that the greatest export from that country is oil (oil1) or that the country is a major exporter of oil to China (oil2); Institutions is an institutional variable that captures rule of law or accountability; and, Aid is a dummy variable indicating the existence of loan agreements in place, which we use as a proxy for bilateral aid as described by Brautigam (2008) ${ }^{12}$.

Although our model follows Chang and $\mathrm{Ma}(2007)^{13}$ - another useful and related reference is Onyeiwu and Shrestha $(2004)^{14}$ - we go beyond their analysis by including additional behind-the-border variables in order to better capture the drivers that might be pivotal in shaping China's decision to invest in Africa. Our initial estimation procedure is as follows: we first estimate a pooled model for Chinese FDI alone and then for the world's FDI in Africa. This procedure allows us to compare the drivers for China's FDI with those of the world's FDI. Table 1 summarises the estimation results (using the oil1 dummy) while full results are detailed in Tables 2 and 3.

\section{[Tables 1 to 3 here]}

We find that the level of GDP of the host African country is positively related for both Chinese and global FDI. For China, two other macroeconomic factors appear to be important, namely the inflation rate and the degree of openness. The first factor is probably 
related to macroeconomic stability concerns, and, perhaps to a lesser extent, real exchange rate considerations. Regarding the second, it is surprising that the degree of openness affects negatively FDI. One could read this result as an indication that local markets matter to China and that it is trying to leap over the border to serve these. Or, that China could simply be investing in countries that are less integrated into the world economy. As for global FDI, it is positively related with the degree of openness, which implies that more integrated African countries attract larger FDI.

The most disparate result is that oil appears to be associated with higher FDI in the case of China whilst having no relation to world FDI. Moreover, if we use the oil2 dummy in our estimations (so as to consider only those countries from which China imports its oil instead of those rich in oil that export to China and elsewhere), this effect becomes even stronger (the estimated coefficient is 1.759). This implies that China is investing in the same countries from where it is importing oil. As for institutions, neither the rule of law nor accountability is related to Chinese FDI. The same is true for global FDI, however. Finally, we find that there no evidence of FDI-aid complementarities either for Chinese or global FDI ${ }^{15}$.

[Table 4 here]

To ensure a more robust analysis, we also estimate a random effects model, which assumes the existence of an individual effect for each country that is randomly distributed in such a way that it is not correlated with the residuals. We conclude in favour of an unobserved effect through the Breusch-Pagan test, as described in Greene $(1997)^{16}$. In general, our previous findings are confirmed (see Table 4), especially with respect to oil. We find that being an oil exporter to China increases Chinese FDI in that country by a factor of approximately two. The remainder of the results tells us a similar story as those obtained using the pooled regressions.

\section{CONCLUSION}

Both China's FDI and global FDI into Africa have grown substantially in recent times. China's FDI outflow increased from US\$ 628 millions in the mid 1980s to US\$ 50 billions in 2008 while African inward FDI increased from US\$ 2 billion to US\$ 36 billion over the same 
period. In spite of the diversity of its 53 countries, Africa is often perceived to be specific as a host for FDI. Similarly China's specific economy and polity are often perceived to impinge on its outward FDI.

In our paper, we use aggregate data on the drivers of China's FDI in Africa and compare them to those of global FDI in Africa in search of a possible "China-Africa factor". Essentially, we analyse "behind-the-border" variables and see how they affect the volume of FDI in Africa, undertaken either by China or by the world as a whole. We find that this factor comes down to different regression coefficients. The existence of oil is important for China but not so for global FDI. China favours macroeconomic stability, measured by low inflation, as does the world. The degree of openness has a negative effect for China but a positive one for global FDI, which suggests that Hymer's monopolistic motive for investing may be at work. Accountability and rule of law is not important either for Chinese or global FDI and FDI-Aid complementarities are absent in both cases. We plan to use more refined governance indicators to verify our results' robustness in future research, as well as more disaggregated data and a larger sample period.

In answering our question: "Is China specific when it comes to investing in Africa?" we conclude that: yes, it is different, on the one hand, as the existence of oil and a lower degree of openness seem to attract Chinese FDI, possibly due to resource-seeking and industrial organization concerns. On the other hand, it is the same as the world when one considers macroeconomic stability, aid complementarity and institutions. We find no evidence for the claim that Chinese outward FDI brings "no strings attached". From this perspective, global and Chinese FDI are indistinguishable. In the end, China is different, and yet the same, when it comes to the drivers of FDI in Africa. 


\section{FIGURES}



Figure 1. African inward and outward FDI (source: UNCTAD) Unit: millions of dollars at current prices.

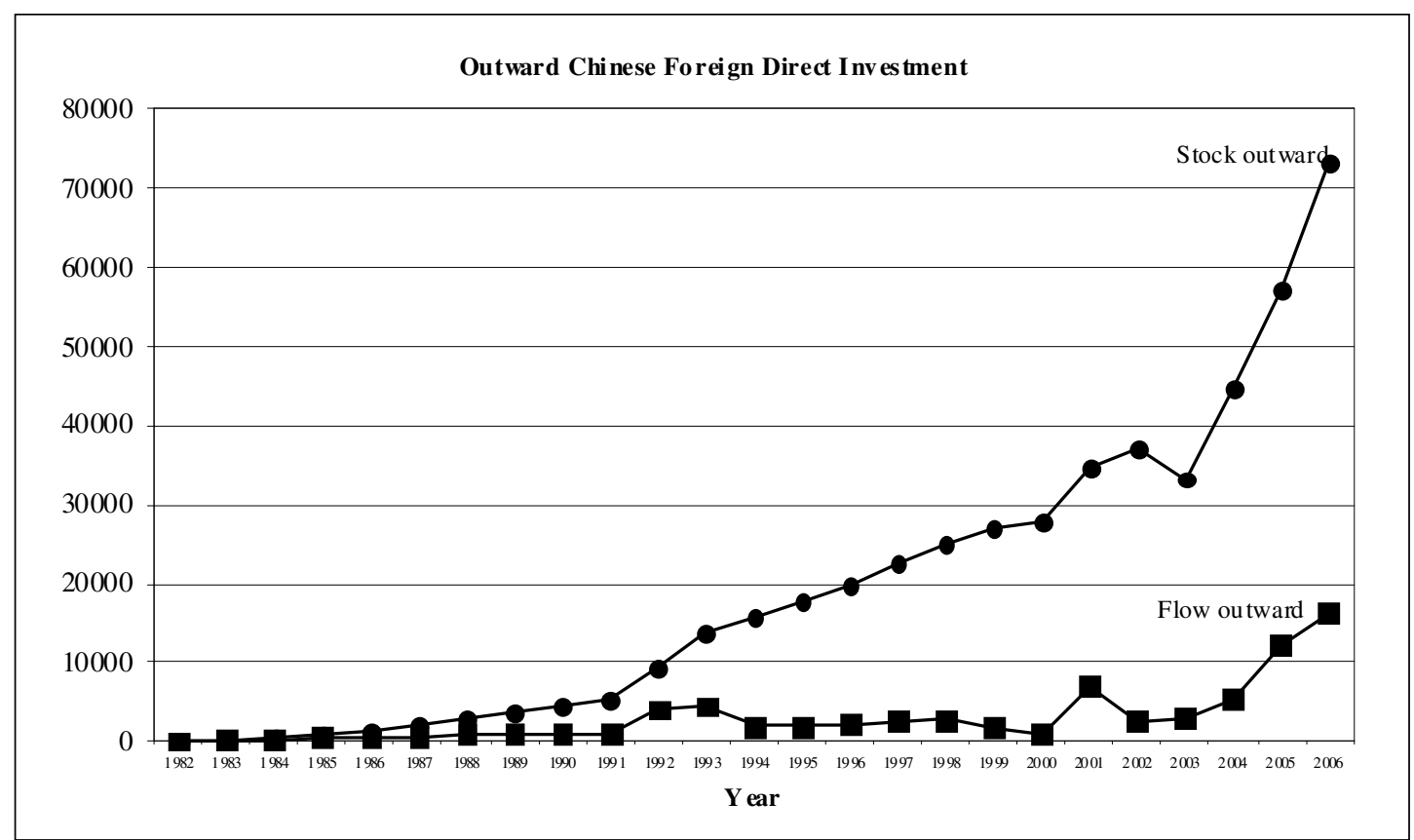

Figure 2. Chinese Foreign Direct Investment (source: UNCTAD) Unit: millions of dollars at current prices. 


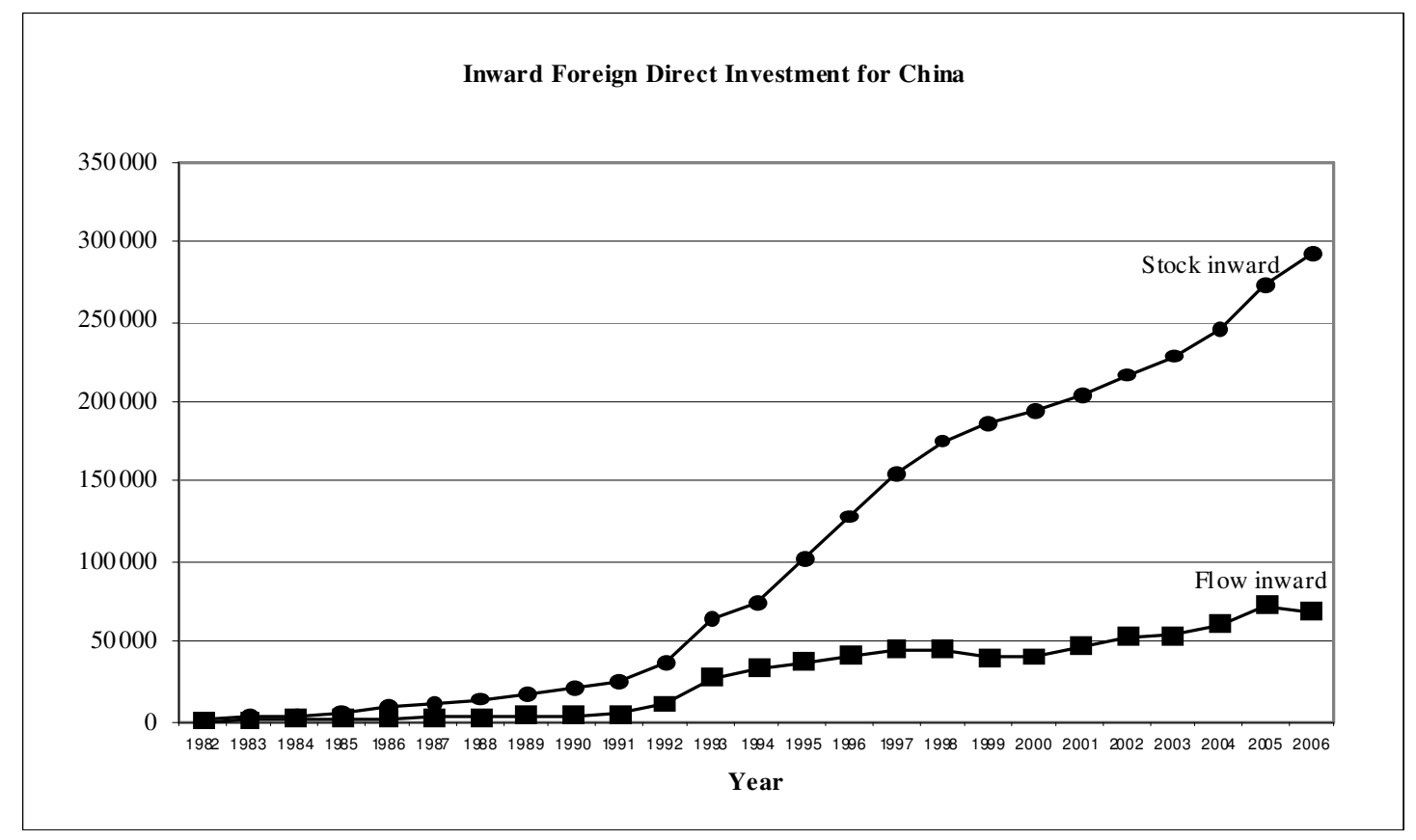

Figure 3. Inward Foreign Direct Investment into China (source: UNCTAD). Unit: millions of dollars at current prices.

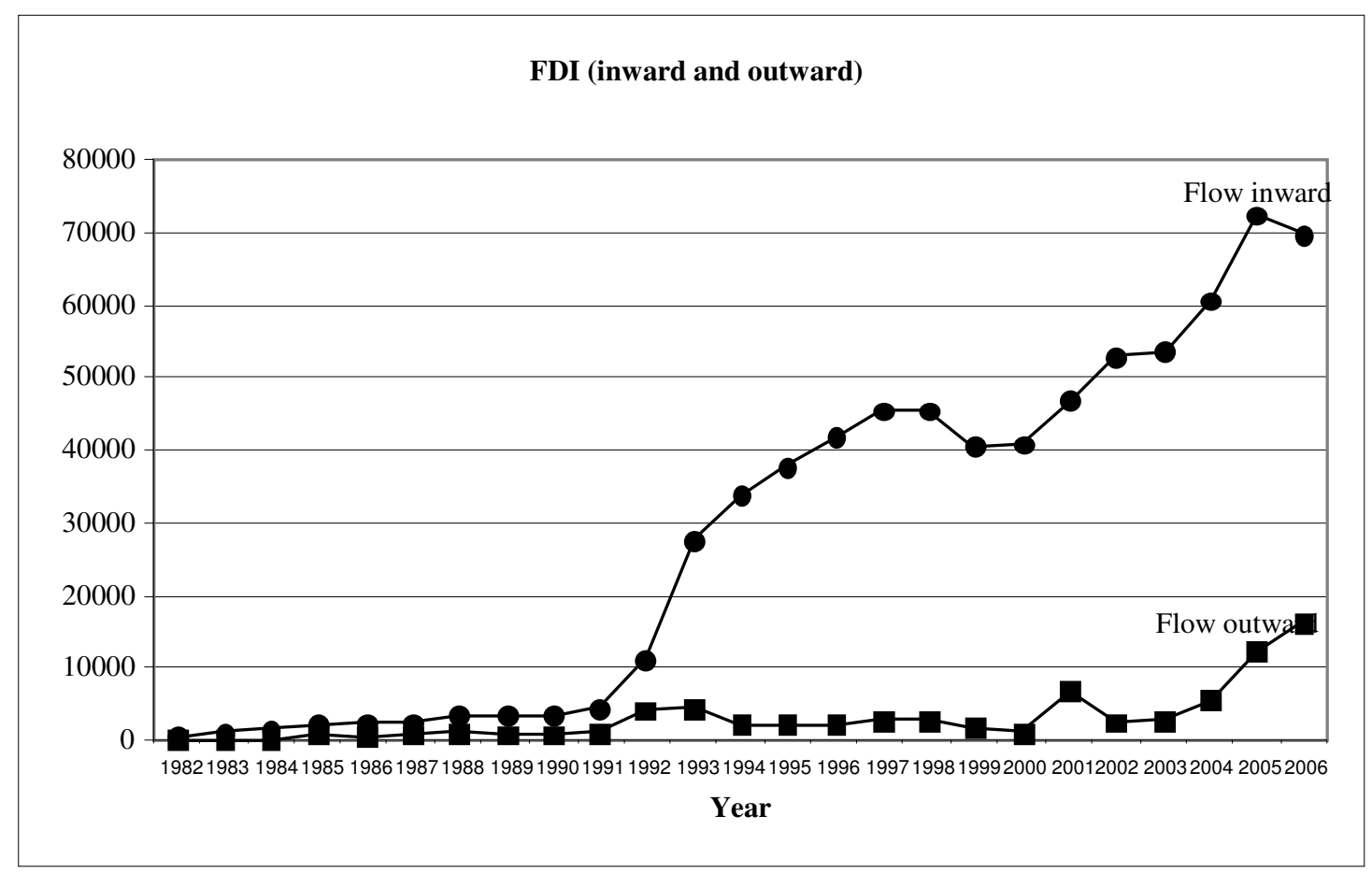

Figure 4. Comparing Inward and outward FDI (source: UNCTAD) Unit: millions of dollars at current prices. 




Figure 5. China's outward FDI flow per region (source: Statistical Bulletin of China's Outward Foreign Direct Investment, 2006) Unit: millions of current US \$.

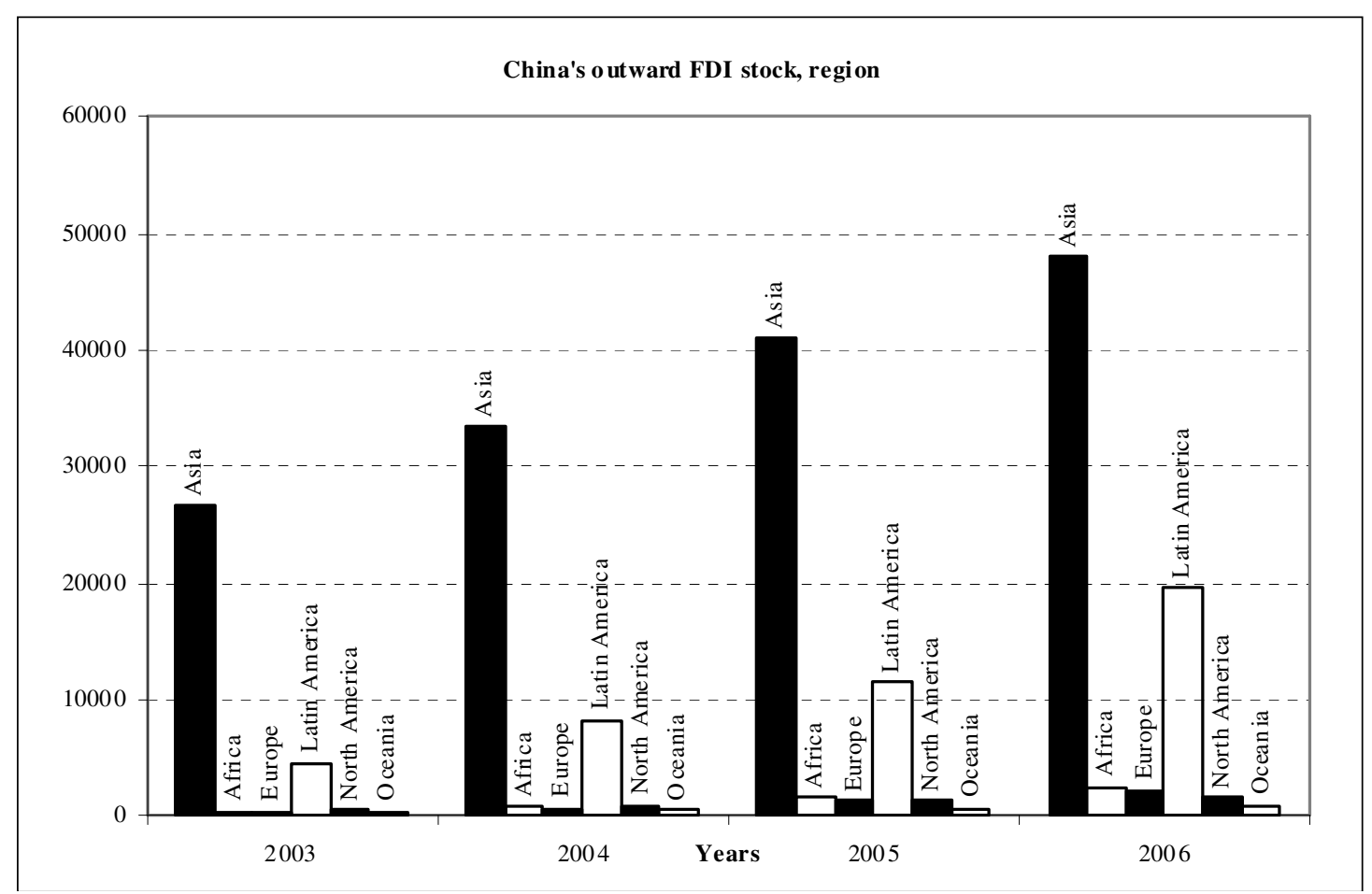

Figure 6. China's outward FDI stock per region (source: Statistical Bulletin of China's Outward Foreign Direct Investment, 2006) Unit: millions of current US \$. 


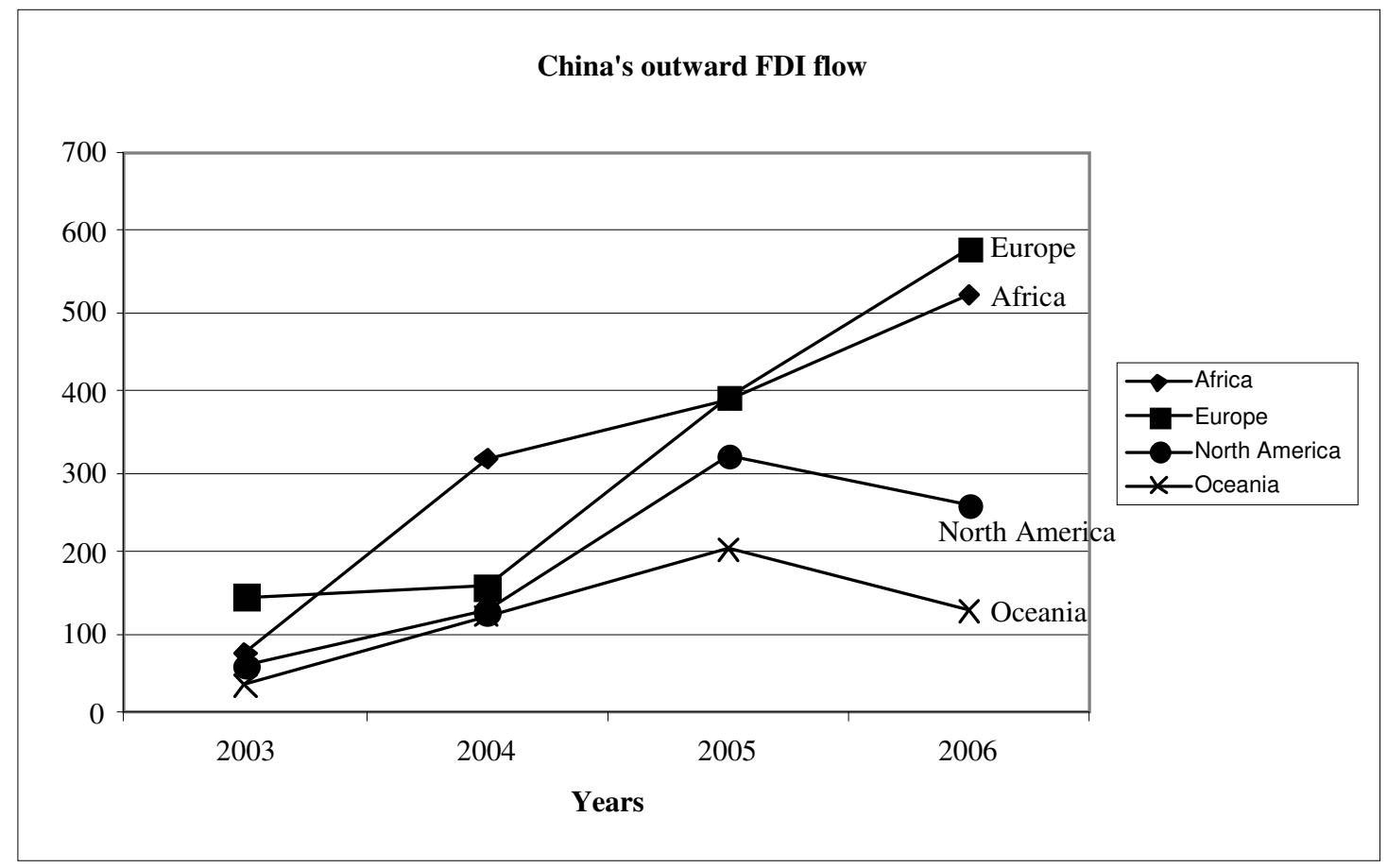

Figure 7. China's outward FDI flow per region (source: Statistical Bulletin of China's Outward Foreign Direct Investment, 2006) Unit: millions of current US \$. 
TABLES

Table 1. Summary of Determinants of FDI into Africa

\begin{tabular}{|c|c|c|}
\hline Effect of row on column & China & World \\
\hline GDP & 0.431 & 0.843 \\
\hline Openness & -0.011 & 0.015 \\
\hline Inflation & -0.007 & -0.007 \\
\hline Oil dummy & 1.759 & - \\
\hline
\end{tabular}

Source: Appendix Tables. The estimates are significant at the $\mathbf{5 \%}$ level

Table 2. Pooled Estimation Results: Dependent variable - Chinese FDI (log)

\begin{tabular}{|c|c|c|c|c|c|c|c|c|c|}
\hline & \multicolumn{3}{|c|}{ using oil1 } & \multicolumn{3}{|c|}{ using oil2 } & \multicolumn{3}{|c|}{ using oil2 } \\
\hline & Estimate & $\begin{array}{l}\text { Robust } \\
\text { Std. } \\
\text { Error }\end{array}$ & $p$-value & Estimate & $\begin{array}{l}\text { Robust } \\
\text { Std. Error }\end{array}$ & $\mathrm{p}$-value & Estimate & $\begin{array}{l}\text { Robust } \\
\text { Std. } \\
\text { Error }\end{array}$ & $p$-value \\
\hline Constant & $-12.66^{* *}$ & 2.656 & 0.00 & $-10.517^{* *}$ & 2.96 & 0.001 & $-9.397^{* *}$ & 3.032 & 0.003 \\
\hline LogGDP & $0.444^{* *}$ & 0.143 & 0.002 & $0.421^{* *}$ & 0.156 & 0.008 & $0.431^{* *}$ & 0.154 & 0.006 \\
\hline LogSurface & 0.101 & 0.123 & 0.411 & 0.127 & 0.125 & 0.313 & 0.122 & 0.129 & 0.346 \\
\hline LogPop & 0.105 & 0.159 & 0.511 & 0.006 & 0.161 & 0.97 & -0.039 & 0.163 & 0.812 \\
\hline Openness & -0.0057 & 0.005 & 0.235 & $-0.009^{*}$ & 0.005 & 0.053 & $-0.011 * *$ & 0.005 & 0.028 \\
\hline Inflation & $-0.008^{* *}$ & 0.002 & 0.00 & $-0.008^{* *}$ & 0.002 & 0.00 & $-0.007 * *$ & 0.002 & 0.00 \\
\hline Oil & $1.299 * *$ & 0.407 & 0.002 & $1.605^{* *}$ & 0.611 & 0.01 & $1.759 * *$ & 0.594 & 0.004 \\
\hline Institutions & 0.025 & 0.315 & 0.936 & 0.066 & 0.349 & 0.85 & 0.0961 & 0.345 & 0.781 \\
\hline Aid & 0.527 & 0.338 & 0.122 & 0.56 & 0.336 & 0.10 & 0.308 & 0.367 & 0.40 \\
\hline Year & \multicolumn{3}{|l|}{ No } & \multicolumn{3}{|l|}{ No } & \multicolumn{3}{|l|}{ Yes } \\
\hline R2 & \multicolumn{3}{|l|}{0.41} & \multicolumn{3}{|l|}{0.40} & \multicolumn{3}{|l|}{0.42} \\
\hline $\mathrm{F}$ & \multicolumn{3}{|l|}{$16.49 * *$} & \multicolumn{3}{|l|}{$15.43^{* *}$} & \multicolumn{3}{|l|}{$14.52^{* *}$} \\
\hline $\mathrm{N}$ & \multicolumn{3}{|l|}{109} & \multicolumn{3}{|l|}{109} & \multicolumn{3}{|l|}{109} \\
\hline
\end{tabular}


Table 3. Pooled Estimation Results: Dependent variable - World FDI (log)

\begin{tabular}{|c|c|c|c|c|c|c|}
\hline & \multicolumn{3}{|c|}{ using oil1 } & \multicolumn{3}{|c|}{ using oil1 } \\
\hline & Estimate & $\begin{array}{l}\text { Robust Std. } \\
\text { Error }\end{array}$ & $p$-value & Estimate & $\begin{array}{l}\text { Robust } \\
\text { Std. Error }\end{array}$ & $p$-value \\
\hline Constant & $-3.407^{*}$ & 2.047 & 0.09 & -3.362 & 2.101 & 0.113 \\
\hline LogGDP & $0.814^{* *}$ & 0.103 & 0.00 & $0.843^{* *}$ & 0.113 & 0.00 \\
\hline LogSurface & $0.22^{* *}$ & 0.099 & 0.029 & $0.228^{* *}$ & 0.095 & 0.018 \\
\hline LogPop & -0.193 & 0.147 & 0.193 & -0.231 & 0.151 & 0.129 \\
\hline Openness & $0.015^{* *}$ & 0.003 & 0.00 & $0.015^{* *}$ & 0.003 & 0.00 \\
\hline Inflation & $-0.008 * *$ & 0.0014 & 0.00 & $-0.007^{* *}$ & 0.002 & 0.00 \\
\hline Oil & 0.371 & 0.270 & 0.173 & 0.268 & 0.283 & 0.347 \\
\hline Institutions & -0.187 & 0.184 & 0.313 & -0.26 & 0.195 & 0.185 \\
\hline Aid & 0.155 & 0.099 & 0.122 & 0.161 & 0.099 & 0.109 \\
\hline Year dummies & \multicolumn{3}{|l|}{ No } & \multicolumn{3}{|l|}{ Yes } \\
\hline R2 & \multicolumn{3}{|l|}{0.67} & \multicolumn{3}{|l|}{0.68} \\
\hline $\mathrm{F}$ & \multicolumn{3}{|l|}{$30.47^{* *}$} & \multicolumn{3}{|l|}{$22.21 * *$} \\
\hline $\mathrm{N}$ & \multicolumn{3}{|l|}{109} & \multicolumn{3}{|l|}{109} \\
\hline
\end{tabular}

Table 4. Random Effects Estimation

\begin{tabular}{|c|c|c|c|c|c|c|c|c|c|}
\hline & \multicolumn{3}{|c|}{ Chinese FDI (log, using oil1) } & \multicolumn{3}{|c|}{ Chinese FDI (log, using oil2) } & \multicolumn{3}{|c|}{ World FDI (log, using oil1) } \\
\hline & Estimate & $\begin{array}{l}\text { Robust } \\
\text { Std. } \\
\text { Error }\end{array}$ & $p$-value & Estimate & $\begin{array}{l}\text { Robust } \\
\text { Std. } \\
\text { Error }\end{array}$ & $p$-value & Estimate & $\begin{array}{l}\text { Robust } \\
\text { Std. } \\
\text { Error }\end{array}$ & p-value \\
\hline Constant & $-12.472^{* *}$ & 3.045 & 0.00 & $-10.59 * *$ & 3.315 & 0.001 & -2.035 & 3.045 & 0.504 \\
\hline LogGDP & $0.418^{* *}$ & 0.141 & 0.003 & $0.396 * *$ & 0.155 & 0.011 & $0.712^{* *}$ & 0.103 & 0.00 \\
\hline LogSurface & 0.121 & 0.145 & 0.404 & 0.146 & 0.148 & 0.323 & 0.244 & 0.163 & 0.135 \\
\hline LogPop & 0.115 & 0.185 & 0.535 & 0.029 & 0.191 & 0.878 & -0.036 & 0.22 & 0.869 \\
\hline Openness & -0.005 & 0.005 & 0.309 & -0.0082 & 0.0052 & 0.113 & $0.018 * *$ & 0.004 & 0.00 \\
\hline Inflation & $-0.009 * *$ & 0.002 & 0.00 & $-0.009 * *$ & 0.002 & 0.00 & $-0.007^{* *}$ & 0.002 & 0.00 \\
\hline Oil & $1.205^{* *}$ & 0.452 & 0.008 & $1.407 * *$ & 0.699 & 0044 & 0.445 & 0.368 & 0.227 \\
\hline Institutions & -0.0104 & 0.38 & 0.978 & 0.0169 & 0.423 & 0.968 & -0.045 & 0.236 & 0.849 \\
\hline Aid & 0.407 & 0.341 & 0.232 & 0.443 & 0.337 & 0.190 & 0.049 & 0.094 & 0.604 \\
\hline $\mathrm{R} 2$ & \multicolumn{3}{|l|}{0.41} & \multicolumn{3}{|l|}{0.40} & \multicolumn{3}{|l|}{0.67} \\
\hline Wald chi2 & \multicolumn{3}{|l|}{$99.76 * *$} & \multicolumn{3}{|l|}{$89.21 * *$} & \multicolumn{3}{|l|}{$118.00 * *$} \\
\hline $\mathrm{N}$ & \multicolumn{3}{|l|}{109} & \multicolumn{3}{|l|}{109} & \multicolumn{3}{|l|}{108} \\
\hline $\begin{array}{l}\text { Breusch } \\
\text { Pagan test }\end{array}$ & \multicolumn{3}{|l|}{$11.64 * *$} & \multicolumn{3}{|l|}{$11.21^{* *}$} & \multicolumn{3}{|l|}{$31.16^{* *}$} \\
\hline $\begin{array}{l}\text { Hausman } \\
\text { test }\end{array}$ & \multicolumn{3}{|c|}{$6.04(p$-value $=0.42)$} & \multicolumn{3}{|c|}{$6.92(p-$ value $=0.328)$} & \multicolumn{3}{|c|}{$7.39(p$-value $=0.286)$} \\
\hline & & & & & & & & & \\
\hline
\end{tabular}

* denotes significance at the $10 \%$ level; ${ }^{* *}$ denotes significance at the $5 \%$ level. 


\section{NOTES AND REFERENCES}

${ }^{1}$ Wang, J. (2007), What Drives China's Growing Role in Africa? IMF Working Paper, 07/211.

${ }^{2}$ Hymer, S. (1976), The International Operations of National Firms: A Study of Foreign Direct Investment: MIT Press, Cambridge, MA.

${ }^{3}$ Williamson, O. (1975), Markets and Hierarchies: Analysis and Antitrust Implications: A Study of the Economics of Internal Organizations, New York: Free Press.

${ }^{4}$ Dunning, J. (1993), The Globalization of Business, London: Routlege.

${ }^{5}$ Zhou, Y. and Lall, S. (2005), The impact of China's FDI surge on FDI in South-East Asia: Panel Data analysis for 1986-2001. Transnational Corporations, 14(1), April.

${ }^{6}$ Asiedu, E. (2002), On the Determinants of Foreign Direct Investment to Developing Countries: Is Africa Different?. World Development, 30(1): 107-119.

${ }^{7}$ Asiedu, E. and Lien, D. (2004) Capital Controls and Foreign Direct Investment. World Development, 32(3): 479490.

8 Broadman, H. (2007), Africa's Silk Road: China and India's New Economic Frontier. The World Bank, Washington.

${ }^{9}$ MOFCOM (2006), Statistical Bulletin of China's Outward Foreign Direct Investment. Ministry of Commerce.

${ }^{10}$ Brautigam, D. (2008), China's African Aid: Transatlantic Challenges. International Development Program, School of International Service, American University, Washington DC.

${ }^{11}$ Kaufmann, D., Kraay A. and Mastruzzi, M. (2006), Governance Matters V: Governance Indicators for 19962005. World Bank Policy Research, 4012, September.

${ }^{12}$ For the world as whole, we extract the data on aid provided to each African country from the WDI.

${ }^{13}$ Chang, L. and Ma, Z. (2007), China's Outward FDI: Past and Future. Renmin University of China Working Paper, 200706001E. Available at http://www.nber.org/books/china07/cwt07/cheng.pdf (accessed 28 February 2008).

${ }^{14}$ Onyeiwu, S. and Shrestha, H. (2004), Determinants of Foreign Direct investment in Africa, Journal of Developing Societies, 20: 89-106.

${ }^{15}$ This result may be attributable, in part, to the difficulty in accurately measuring Chinese aid, as is also recognised by other studies.

${ }^{16}$ Greene, W. (1997), Econometric Analysis: London: Prentice Hall. 